\title{
Melatonin regulates tumor aggressiveness under acidosis condition in breast cancer cell lines
}

\author{
NATHÁLIA MARTINS SONEHARA ${ }^{1,2}$, JÉSSICA ZANI LACERDA ${ }^{2,3}$, BRUNA VICTORASSO JARDIM-PERASSI ${ }^{1,2}$, \\ RUBENS DE PAULA JR ${ }^{1,2}$, MARINA GOBBE MOSCHETTA-PINHEIRO ${ }^{1,2}$, YNAIÁ SANTOS TRABA SOUZA ${ }^{2}$, \\ JÚLIA CAROLINA JUNQUEIRA DE ANDRADE ${ }^{2}$ and DEBORA APARECIDA PIRES DE CAMPOS ZUCCARI ${ }^{1-3}$ \\ ${ }^{1}$ Faculty of Medicine of São José do Rio Preto (FAMERP), Department of Molecular Biology; \\ ${ }^{2}$ Laboratory of Cancer Molecular Investigation (LIMC), Department of Molecular Biology, \\ Faculty of Medicine of São José do Rio Preto (FAMERP), São José do Rio Preto, SP 15090-000; \\ ${ }^{3}$ Sao Paulo State University ‘Julio de Mesquita Filho' (UNESP), São José do Rio Preto, SP 15054-000, Brazil
}

Received October 4, 2017; Accepted April 26, 2018

DOI: $10.3892 / 01.2018 .9758$

\begin{abstract}
Breast cancer progression is composed of multiple steps that are influenced by tumor cell adaptations to survive under acidic conditions in the tumor microenvironment. Regulation of this cell survival behavior is a promising strategy to avoid cancer development. Melatonin is a natural hormone produced and secreted by the pineal gland capable of modulating different biological pathways in cancer. Although the anti-cancer effects of melatonin are currently widespread, its role in the acid tumor microenvironment remains poorly understood. The aim of the present study was to investigate the effect of low $\mathrm{pH}$ (6.7) on human breast cancer cell lines MCF-7 and MDA-MB-231, and the effectiveness of melatonin in acute acidosis survival mechanisms. Cell viability was measured by a MTT assay and the protein expression of glucose transporter (GLUT)-1, Ki-67 and caspase-3 was evaluated by immunocytochemical (ICC) analysis following low $\mathrm{pH}$ media and melatonin treatment. In both cell lines the viability was decreased after melatonin treatment $(1 \mathrm{mM})$ under acidosis conditions for $24 \mathrm{~h}$. ICC analysis showed a significant increase in GLUT-1 and Ki-67 expression at $\mathrm{pH}$ 6.7, and a decrease after treatment with melatonin for 12 and $24 \mathrm{~h}$. The low $\mathrm{pH}$ media decreased the expression of caspase-3, which was increased after melatonin treatment for 12 and $24 \mathrm{~h}$. Overall, the results of the present study revealed melatonin treatment increases apoptosis, as indicated by changes in caspase-3, and decreases proliferation, indicated by changes to $\mathrm{Ki}-67$, and
\end{abstract}

Correspondence to: Dr Debora Aparecida Pires de Campos Zuccari, Laboratory of Cancer Molecular Investigation (LIMC), Department of Molecular Biology, Faculty of Medicine of São José do Rio Preto (FAMERP), 5416 Brigadeiro Faria Lima Avenue, São José do Rio Preto, SP 15090-000, Brazil

E-mail: debora.zuccari@famerp.br

Key words: low pH, acidosis, breast cancer, melatonin, metabolism, microenvironment
GLUT-1 protein expression under acute acidosis conditions in breast cancer cell lines.

\section{Introduction}

Breast cancer is the most common tumor among women and the fifth leading cause of cancer-related death worldwide confirmed by high rates of incidence and mortality $(1,2)$. Breast tumors are very heterogeneous with multiple histological and molecular subtypes and features, and thus, one of the major challenges for clinical prediction and therapy response assessment $(3,4)$. Therefore, the understanding of the molecular characteristics of tumors has contributed to a better prognosis and development of new therapeutic strategies (5-8).

Currently, the classification of breast cancer is based on estrogen receptor (ER), progesterone receptor (PR) and growth factor receptor epidermal 2 (HER-2/neu). The status of these receptors is used within the clinical routine and allows establishment of tumor subtypes with distinct clinical behavior and individualized treatment (9). Approximately 60 to $75 \%$ of breast cancers express ER-a and/or PR, which are markers and determinants for the use of endocrine therapies $(10,11)$. Conversely, triple negative breast cancer (TNBC) is a heterogeneous subgroup of breast cancer characterized by the absence of expression of ER, PR and HER-2/neu. TNBC represents approximately $15-20 \%$ of all breast cancer cases and is generally considered as the most severe subgroup of breast cancer associated with the occurrence of metastases and poor survival of patients (12-14).

In recent decades, it has become clear that this type of cancer can no longer be considered as a single disease entity. It is essential to know about the tumor microenvironment and adaptations of the cells beyond the analysis of molecular characteristics of breast cancer. During the tumorigenesis, cancer cells adapt their metabolic pathways to meet the high-energy demands required for their accelerated growth and proliferation and the associated metabolic stresses (15). Once the tumor size reaches more than 1-2 $\mathrm{mm}$ of diameter size and the growth outpaces that of adequate vasculature, oxygen and nutrient delivery become insufficient. This dynamic interplay 
between the normal stroma and the malignant cells coupled with inevitable hypoxia is common in any solid tumor microenvironment (16).

The environmental stress of hypoxia triggers molecular changes especially the suppression of the degradation of hypoxia-inducible factors (HIFs) that facilitate metabolic adaptations in order to maintain the tumor growth (17-20). One important cell feature capable of modulating the HIFs expression is the activation of glucose transporter (GLUT)-1 which facilitates the glucose transportation into the cells which is essential for the malignant cells to adapt their metabolism under hypoxia conditions $(17,21)$. Instead the normal cells, the tumor cells show anaerobic glycolysis as predominant metabolic activity even in presence of oxygen a process called Warburg effect $(22,23)$. Once that the cells are on anaerobic glycolysis mode, the levels of lactate and hydrogen increase forcing them to export it out and hence decreasing the $\mathrm{pH}$ and acidifying the extracellular matrix $(19,24,25)$. The acid effect is able to induce apoptosis in healthy cells but the malignant cells have adaptive feature which avoid this mechanism enhancing the advantages on the proliferation and progression (25).

Based on those prior features, the hypoxia and acidification in the tumor microenvironment are key factors that give advantages to the malignancy of the tumor cells (25-28). Therefore, the development of models that mimic the tumor microenvironment heterogeneity has become important to find new therapeutic targets to eliminate different populations of tumor cells. In this context, we highlight melatonin, an indole hormone, mainly produced and secreted by the pineal gland and also can be found in all biological fluids including cerebrospinal fluid, saliva, bile, synovial fluid, amniotic fluid, and breast milk $(29,30)$. The melatonin's actions involved in cancer are varied, including: Antioxidant effects, regulation of the ER expression and transactivation, modulation of the enzymes involved in the local synthesis of estrogens, modulation of cell cycle and induction of apoptosis, inhibition of telomerase activity, inhibition of metastasis, prevention of circadian disruption, antiangiogenics, epigenetic effects, stimulation of cell differentiation and activation of the immune system $(31,32)$. Researchers have focused in the role of melatonin in metastasis and proliferation providing results that show inhibition in the proliferation as well as invasion/migration of human cells disrupting the tube formation and counteracted the VEGF-stimulated tubular network formation in vitro (33). Another work has found that melatonin (both endogenous and exogenous) significantly represses this invasive/metastatic phenotype through a mechanism that involves the suppression of EMT, either by promoting mesenchymal-to-epithelial transition, and/or by inhibiting key signaling pathways involved in later stages of metastasis (34). However, the comprehension melatonin function on low $\mathrm{PH}$ microenvironment is fundamental to verify its use as adjuvant treatment in breast cancer.

The aim of this study was therefore to determine the capability of melatonin on the modulation of proliferation and apoptosis in acid microenvironment of ER-positive tumor cell line MCF-7 and triple-negative tumor cell line MDA-MB-231 through the expression of proteins involved in the tumorigenic process.

\section{Materials and methods}

Cell culture. This study was performed using human breast cancer cell lines MCF-7 [American Type Culture Collection, (ATCC), Manassas, VA, USA] and MDA-MB-231 (ATCC). Both cell lines were grown in $75 \mathrm{~cm}^{2}$ flasks (Sarstedt, Nümbrecht, Germany) with DMEM (Thermo Fisher Scientific, Inc., Waltham, MA, USA) and RPMI-1640 medium (Thermo Fisher Scientific, Inc.), respectively and supplemented with $10 \%$ fetal bovine serum (FBS; Cultilab, Campinas, SP, Brazil), penicillin $(100 \mathrm{U} / \mathrm{ml})$ and streptomycin $(100 \mathrm{mg} / \mathrm{ml})$ (Sigma-Aldrich; Merck KGaA, Darmstadt, Germany). Both cell lines were cultured in a humidified chamber with $5 \% \mathrm{CO}_{2}$ and at $37^{\circ} \mathrm{C}$.

Experimental conditions. The MCF-7 and MDA-MB-231 cells were seeded in complete medium with initial number of $2.1 \times 10^{6}$ cells. Six experimental conditions were performed. Group I: Control group, cells grown in complete medium, maintained at $\mathrm{pH}$ 7.4; group II: Cells grown in culture medium (pH 7.4) and treated with vehicle (ethanol 100\%: PBS) for $24 \mathrm{~h}$; group III: Cells grown in culture medium (pH 7.4) and treated with melatonin (1 mM) (Sigma-Aldrich; Merck KGaA) for $24 \mathrm{~h}$ (35); group IV: Cells grown for $24 \mathrm{~h}$ in complete medium with MES, pHadjusted to 6.7 (36); group V: Cells cultured in low $\mathrm{pH}$ medium with MES reagent (4-Morpholineethanesulfonic acid monohydrate; Sigma-Aldrich; Merck KGaA) and treated with melatonin ( $1 \mathrm{mM}$ ) for $24 \mathrm{~h}$; group VI: Cells cultured in low $\mathrm{pH}$ medium with MES for $12 \mathrm{~h}$, and then treated with melatonin $(1 \mathrm{mM})$ for an additional $12 \mathrm{~h}$ in the same medium. It should be emphasized here that the concentration of $1 \mathrm{mM}$ melatonin used for the treatment of the cells was defined according to the literature. This is the pharmacological concentration used in several studies about the effects of melatonin in breast cancer $(35,37,38)$. For an induction of the acute acidosis condition, the growth medium was replaced for a medium supplemented with $25 \mathrm{mM}$ buffer 2-(N-Morpholino) ethanesulfonic acid (MES; Sigma-Aldrich; Merck KGaA) and the $\mathrm{pH}$ adjusted to 6.7 and maintained for $24 \mathrm{~h}$ (39).

Cell viability. MCF-7 and MDA-MB-231 cells were grown on a 96 well plate (Sarstedt, Nümbrecht, Germany) with $100 \mu \mathrm{l}$ of medium containing $0.05 \times 10^{6}$ cells/well. The cells were incubated under the different experimental conditions described above. Then the cells were washed and pulsed with $10 \mu \mathrm{l}$ of MTT at $0.5 \mathrm{mg} / \mathrm{ml}$ [3-(4,5-Dimethylthiazol-2-yl)-2, 5-diphenyltetrazolium bromide; Thermo Fisher Scientific, Inc.] to each well and the plate was incubated at $37^{\circ} \mathrm{C}$ for $4 \mathrm{~h}$. The solubilization of the MTT formazan crystals was made adding $10 \mathrm{mM}$ SDS-HCl (Thermo Fisher Scientific, Inc.) for $4 \mathrm{~h}$ at $37^{\circ} \mathrm{C}$. Measurement of the absorbance was carried out on ELISA reader (Thermo Fisher Scientific, Inc.) at $570 \mathrm{~nm}$ and the results were expressed as percentage of viable cells compared to the control group. All treatments were performed in triplicate.

Immunocytochemistry. The immunocytochemical (ICC) technique was performed to evaluate the expression of the protein transporter of GLUT-1 (1:1,200; Abcam, Cambridge, UK), Ki-67 (1:200; BioCare, Concord, CA, USA) and cleaved 
Caspase-3 (1:100; BioCare) (Table I). Initially, 0.05x $10^{6}$ cells were attached to 8-well chamber slides (Sarstedt, Newtoon, $\mathrm{NC}$, USA) and maintained at $37^{\circ} \mathrm{C}$ and $5 \% \mathrm{CO}_{2}$. After cellular adherence, cells were incubated at different experimental conditions for $24 \mathrm{~h}$. Subsequently, the chamber slides were removed and the slides were washed with PBS and immediately fixed in $4 \%$ paraformaldehyde for $24 \mathrm{~h}$. After this period, the cells were washed with $1 \mathrm{ml}$ of PBS, blocked with $10 \%$ PBS+BSA (Sigma-Aldrich; Merck KGaA) for $30 \mathrm{~min}$ and with the primary antibody at $4^{\circ} \mathrm{C}$ for $12 \mathrm{~h}$. In sequence, the slides were washed in PBS and incubated with Reveal Biotin-Free Polyvalent DAB (Spring Bioscience, Pleasanton, CA, USA) containing the secondary antibody (Biotinylated antimouse, rabbit, goat immunoglobulins) for one hour. Positive staining was detected using 3,3'-diaminobenzidine (DAB) as a substrate (Thermo Fisher Scientific, Inc.) and counterstained with hematoxylin for $40 \mathrm{sec}$. The slides were mounted with medium Erv-Mount (EasyPath, Erviegas, SP, Brazil). All ICC reactions were performed with a positive control for the tested antibody and a negative control was obtained by omitting the primary antibody. For densitometric analyses, three slides from each experimental group were used, and 20 points were analyzed in three fields to obtain an average related to the intensity of immunoreactivity. At the end of the procedure, the expression of the antibodies was quantified by densitometry technique with the Nikon Eclipse E200 microscope (Nikon Corporation, Tokyo, Japan). The image analyzer and values obtained as arbitrary units (a.u.) were performed using the software HistoQuant.

Statistical analysis. All data were expressed as mean \pm standard error comparison between treatment with melatonin and the vehicle group using the Student t-test and analysis of variance (ANOVA), followed by test Bonferroni with GraphPad Prism 5.0 software (GraphPad Software, Inc., La Jolla, CA, USA). All assays were performed in three independent experiments done in triplicate and $\mathrm{P}<0.05$ was considered to indicate a statistically significant difference.

Ethical considerations. The study was discharged from the ethics committee of the Faculty of Medicine of São José do Rio Preto, Sao Paulo, Brazil because it was performed with breast cancer cell lines.

\section{Results}

Effects of low pH microenvironment and melatonin treatment on the cell viability of MCF-7 and MDA-MB-231 cells. The cell viability was investigated under the different experimental conditions via MTT assay. The assay was performed on MCF-7 and MDA-MB-231 cell lines under normal conditions ( $\mathrm{pH} 7.4)$, under acidosis ( $\mathrm{pH}$ 6.7) and with or without treatment with melatonin. The results showed decrease of cell viability of both cells lines under acidosis condition compared to the control group $(\mathrm{P}<0.001$; Fig. 1). The treatment with melatonin in complete medium with $\mathrm{pH} 7.4$ significantly decreased cell viability compared with the control group $(\mathrm{P}<0.001$; Fig. 1). The same effect was observed under acute acidosis when the cells were treated with melatonin for $24 \mathrm{~h}$ or after $12 \mathrm{~h}$ of acidosis induction $(\mathrm{P}<0.001$; Fig. 1). However, the results revealed no significant
Table I. Antibodies used in immunocytochemistry.

\begin{tabular}{|c|c|c|c|}
\hline Antibody & Supplier & Code & Dilution \\
\hline GLUT-1 & Abcam & AB 652 & $1: 1,200$ \\
\hline Ki-67 & $\begin{array}{l}\text { BioCare } \\
\text { medical }\end{array}$ & CRM 325 & $1: 200$ \\
\hline $\begin{array}{l}\text { Caspase-3 } \\
\text { (cleaved) }\end{array}$ & $\begin{array}{l}\text { BioCare } \\
\text { medical }\end{array}$ & СР 229 & $1: 100$ \\
\hline $\begin{array}{l}\text { Secondary } \\
\text { antibody }\end{array}$ & $\begin{array}{l}\text { Spring } \\
\text { biosciences }\end{array}$ & SPD 015 & Ready to use \\
\hline
\end{tabular}

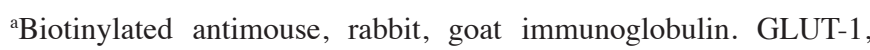
glucose transporter 1 .

differences in cell viability between 12 or $24 \mathrm{~h}$ of melatonin treatment under acidosis (Fig. 1).

Expression of GLUT-1 in MCF-7 and MDA-MB-231 cells. The immunocytochemistry assay to evaluate the expression of GLUT-1 was conducted in MCF-7 (Fig. 2) and MDA-MB-231 cells (Fig. 3) control, melatonin (1 mM), acidosis and acidosis/melatonin at 12 and $24 \mathrm{~h}$. There was no significant difference between cells treated with vehicle (Figs. 2B and 3B) compared to control group (Figs. 2A and 3A). The treatment with melatonin for $24 \mathrm{~h}$ efficiently reduced the expression of GLUT-1 (Figs. 2C and 3C) compared to control cells (Figs. 2A and 3A). Acute exposure to acidic medium increased the expression of GLUT-1 (Figs. 2D and 3D) and decreased after treatment with melatonin for $12 \mathrm{~h}$ (Figs. 2E and 3E) and $24 \mathrm{~h}$ (Figs. 2F and 3F). The densitometric analysis confirmed the reduction of GLUT-1 in cells treated with melatonin after $24 \mathrm{~h}$. A similar effect was observed in the group after acidosis conditions and treatment with melatonin for 12 and $24 \mathrm{~h}$. On the other hand, low $\mathrm{pH}$ environment conditions increased the expression of GLUT-1 ( $\mathrm{P}<0.05$; Figs. $2 \mathrm{G}$ and $3 \mathrm{G})$.

Expression of cell proliferation marker $\mathrm{Ki}-67$ in MCF-7 and MDA-MB-231 cells. The expression of Ki-67 was analyzed in MCF-7 (Fig. 4) and MDA-MB-231 cells (Fig. 5) control, melatonin $(1 \mathrm{mM})$, acidosis and acidosis/melatonin at 12 and $24 \mathrm{~h}$. There was no significant difference when compared cells treated with vehicle (Figs. 4B and 5B) with the control cells (Figs. 4A and 5A). We observed reduced expression of Ki-67 after treatment with melatonin for $24 \mathrm{~h}$ (Figs. 4C and 5C) compared to control cells (Figs. 4A and 5A). After acute acidosis (Figs. 4D and 5D) an increase in Ki-67 was observed and the expression decreased after treatment with melatonin for $12 \mathrm{~h}$ (Figs. 4F and 5F) and $24 \mathrm{~h}$ (Figs. 4E and 5E). The densitometric analysis showed significant decrease in Ki-67 expression in cells treated with melatonin after $24 \mathrm{~h}(\mathrm{P}<0.05)$. A similar effect was observed in both cells lines culture in $\mathrm{pH} 6.7$ and treated with melatonin for 12 and $24 \mathrm{~h}$. However, cells cultured transiently at low $\mathrm{pH}$ increased the expression of Ki-67 (P<0.05; Figs. 4G and 5G).

Expression of cell death marker Caspase-3 (cleaved) in MCF-7 and $M D A-M B-231$ cells. The immunocytochemistry analysis 

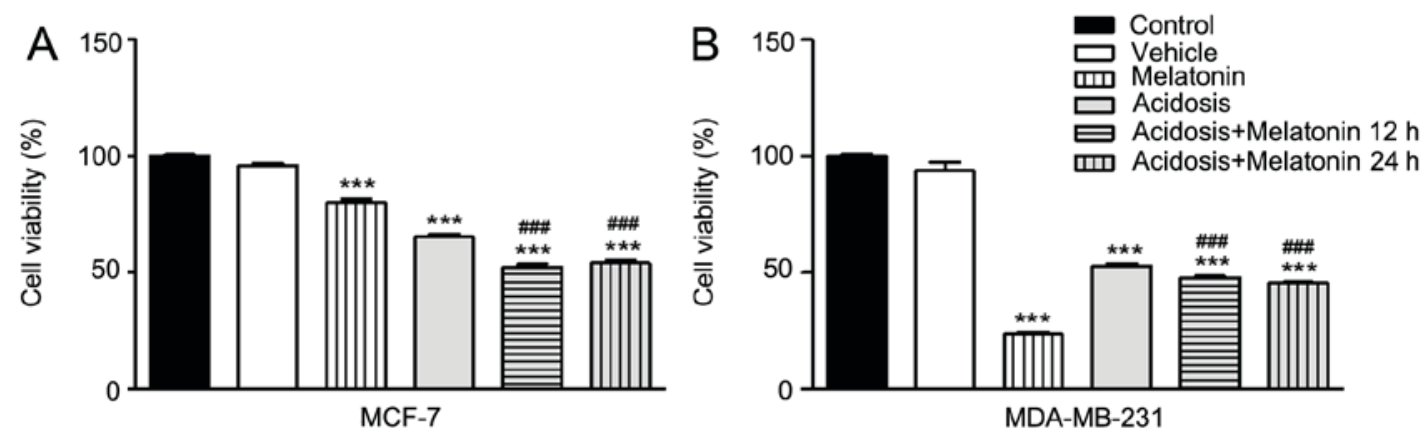

Figure 1. Evaluation of viability of MCF-7 and MDA-MB-231 cell lines subject to different experimental conditions for 24 h. (A) MCF-7 cell line. (B) MDA-MB-231 cell line. The cell viability of both cells line was measured by MTT assay. The cell viability was decrease under acidosis condition and after melatonin treatment $(1 \mathrm{mM})$ for $24 \mathrm{~h}$ in both cell types. Results were obtained as mean \pm SEM densitometric index of three independent experiments done in triplicate. ${ }^{* * *} \mathrm{P}<0.001$ vs. control and ${ }^{\# \# \#} \mathrm{P}<0.001$ vs. acidosis. SEM, standard error of the mean.

A

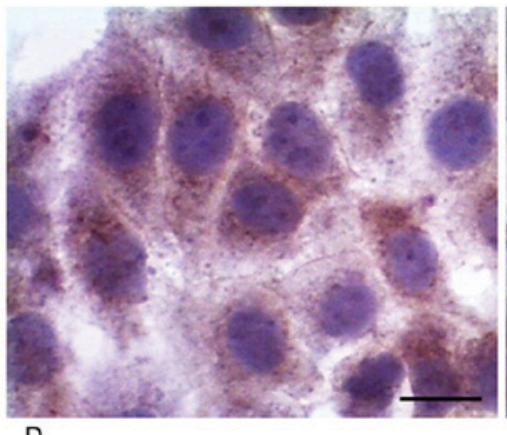

D

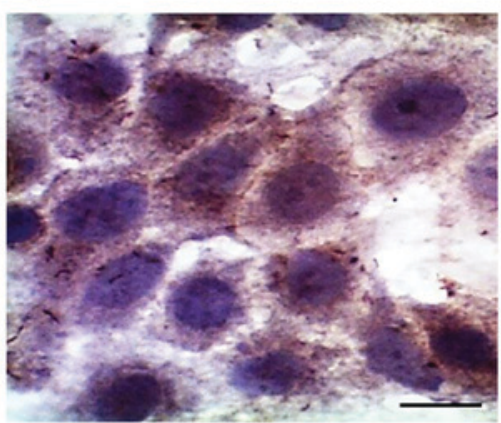

G
B

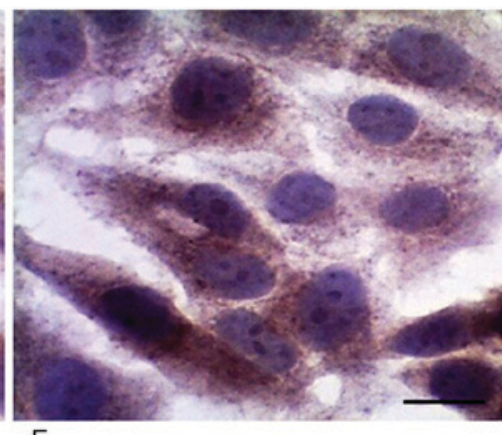

$\mathrm{E}$

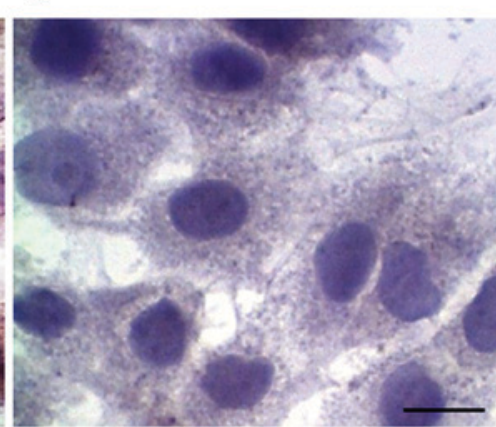

C

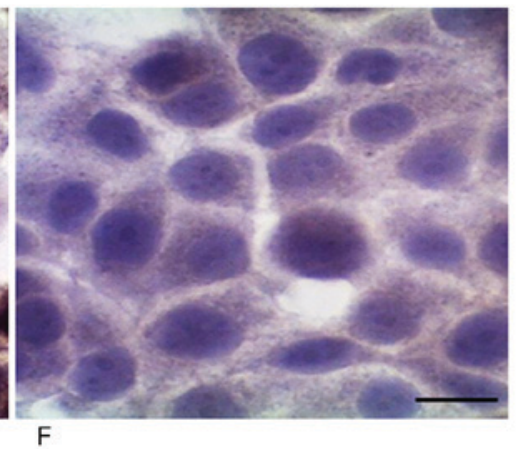

$\mathrm{F}$

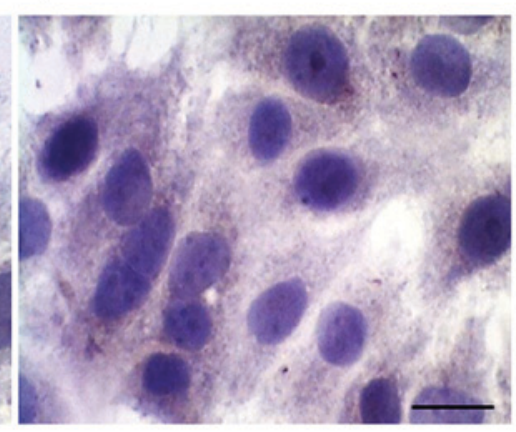

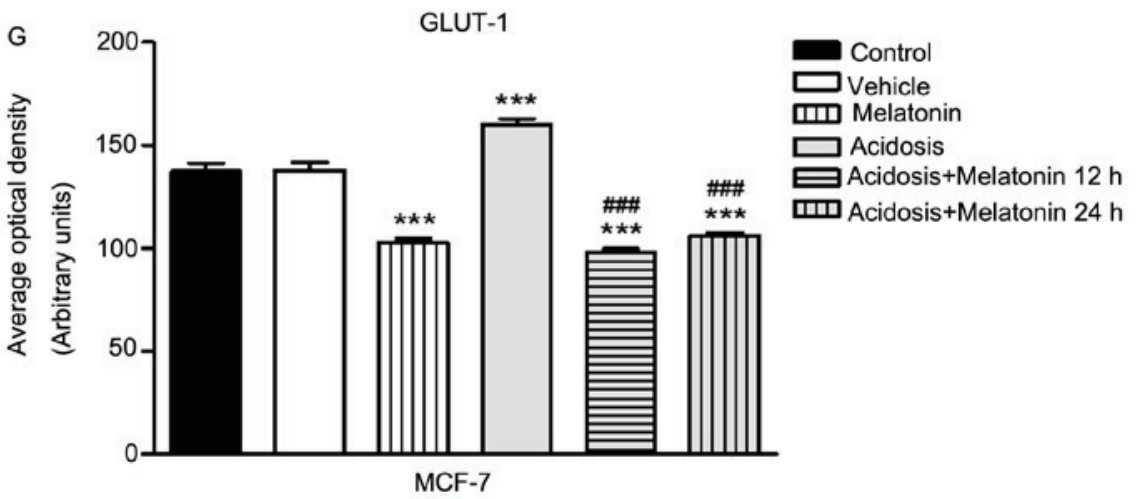

Figure 2. Analysis of the expression GLUT-1 in MCF-7 cells. (A) Control cells (pH 7.2). (B) Cells after treatment with vehicle. (C) Post-treatment with melatonin (1 mM) for $24 \mathrm{~h}$ decreases the expression of GLUT-1. (D) Cells under acidosis (pH 6.7) have increased GLUT-1 expression. (E) Cells exposed to $\mathrm{pH} 6.7$ treated concomitantly with melatonin $(1 \mathrm{mM})$ for $24 \mathrm{~h}$. (F) Cells exposed to the $\mathrm{pH} 6.7$ treated with melatonin $(1 \mathrm{mM})$ for $12 \mathrm{~h}$. Scale bar=10 $\mu \mathrm{m}$. Magnification, $x 40$. (G) Densitometric analysis of GLUT-1 expression. Results were obtained as mean \pm SEM densitometric index of three independent experiments done in triplicate. ${ }^{* * *} \mathrm{P}<0.001$ vs. control; ${ }^{\# \#} \mathrm{P}<0.001$ vs. acidosis. SEM, standard error of the mean; GLUT-1, glucose transporter-1.

to evaluate the expression of cleaved Caspase-3 was conducted in MCF-7 (Fig. 6) and MDA-MB-231 cells (Fig. 7) under the different experimental conditions. There was no significant difference when the cells were compared under normal 
A

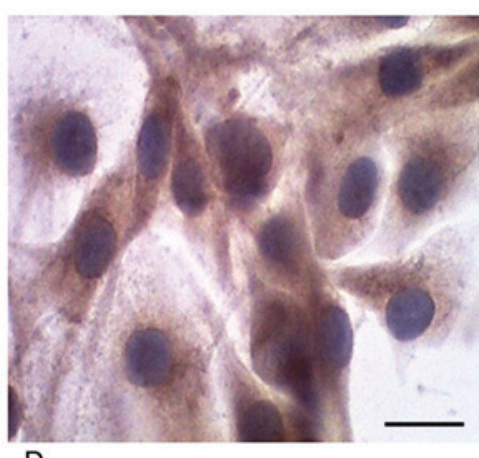

D
B

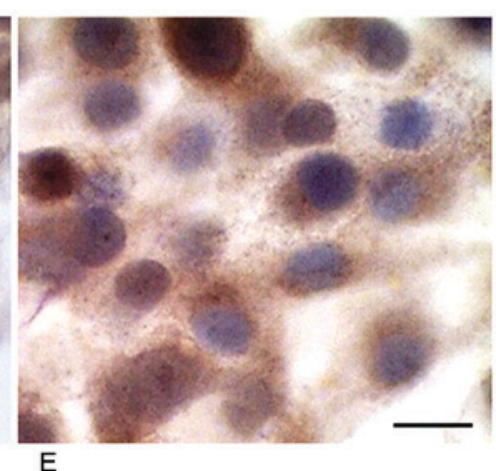

C
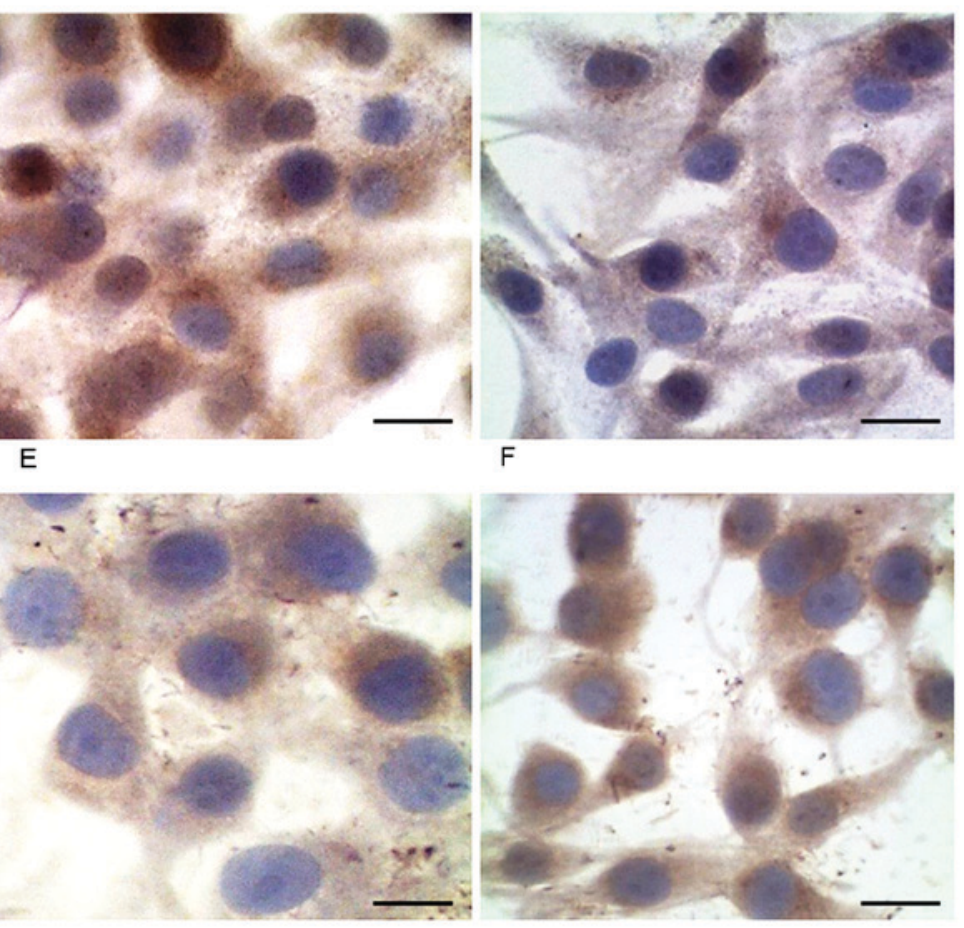

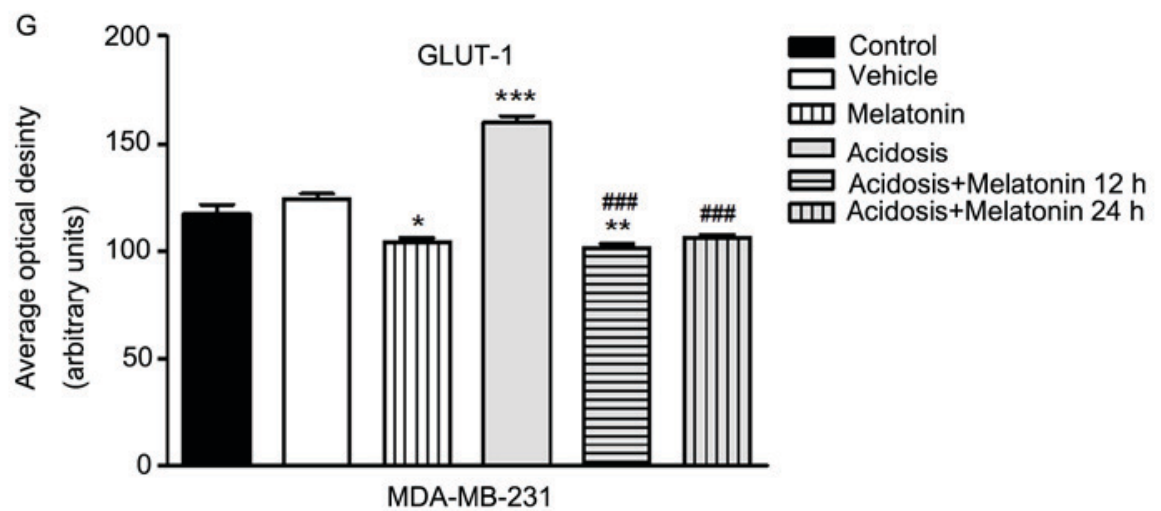

Figure 3. Analysis of expression of GLUT-1 in MDA-MB-231 cells. (A) Control cells (pH 7.2). (B) Cells after treatment with vehicle. (C) Post-treatment with melatonin (1 mM) for $24 \mathrm{~h}$ decreases the expression of GLUT-1. (D) Cells under acidosis (pH 6.7) have increased GLUT-1 expression. (E) Cells exposed to the $\mathrm{pH} 6.7$ treated concomitantly with melatonin $(1 \mathrm{mM})$ for $24 \mathrm{~h}$. (F) Cells exposed to the pH 6.7 treated with melatonin $(1 \mathrm{mM})$ for $12 \mathrm{~h}$. Scale bar=10 $\mu \mathrm{m}$. Magnification, $x 40$. (G) Densitometric analysis of GLUT-1 expression. Results were obtained as mean \pm SEM densitometric index of three independent experiments done in triplicate. ${ }^{*} \mathrm{P}<0.05,{ }^{* * *} \mathrm{P}<0.01,{ }^{* * * *} \mathrm{P}<0.001$ vs. control; ${ }^{\# \# *} \mathrm{P}<0.001$ vs. acidosis. SEM, standard error of the mean; GLUT-1, glucose transporter-1.

growth conditions (Figs. 6A and 7A) with cells treated with vehicle (Figs. 6B and 7B). The treatment with melatonin for $24 \mathrm{~h}$ increases the expression of Caspase-3 (Figs. 6C and 7C) compared to control group (Figs. 6A and 7A). We showed a decrease in Caspase-3 expression in both cells lines grown in low $\mathrm{pH}$ media for $24 \mathrm{~h}$ (Figs. 6D and 7D) and increased after treatment with melatonin for $12 \mathrm{~h}$ (Figs. $6 \mathrm{~F}$ and $7 \mathrm{~F}$ ) and $24 \mathrm{~h}$ (Figs. 6E and 7E). Similarly, densitometry analysis confirmed these observations $(\mathrm{P}<0.05$; Figs. $6 \mathrm{G}$ and $7 \mathrm{G})$.

\section{Discussion}

In this study the effects of melatonin were investigated on the ER-positive tumor cell line MCF-7 and triple-negative tumor cell line MDA-MB-231 under acute acidosis. We showed that low $\mathrm{pH}$ conditions increased the levels of poor prognostic markers in tumor cells and that melatonin can reverse this by decreasing the cell viability, expression of GLUT-1 and Ki-67 and by increasing the expression of Caspase-3.

The inhibitory effect of melatonin on cell viability in MCF-7 and MDA-MB-231 was achieved with the concentration of $1 \mathrm{mM}$ in both low $\mathrm{pH}$ and normal $\mathrm{pH}$ (7.4) medium conditions. In our study, MTT assay also showed that at low $\mathrm{pH}$ conditions the cell viability of MCF-7 and MDA-MB-231 cell lines were reduced compared with control group. Another study also noted that acute exposure to acidic medium reduced the proliferation of MDA-MB-231 cells after $72 \mathrm{~h}$ and that large percentage of these cells were in G1 phase at 24 and $72 \mathrm{~h}$. In addition, both cells lines were grown in $\mathrm{pH} 6.7$ medium for 3 months, under chronic acidosis conditions and had similar growth rates to non-adapted cells using the autophagy mechanism to survive (39).

After investigation of the effect of melatonin on cell viability, we evaluated the expression of GLUT-1 by 
A

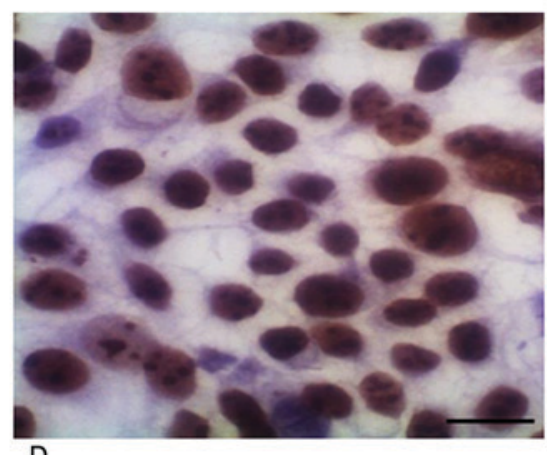

D

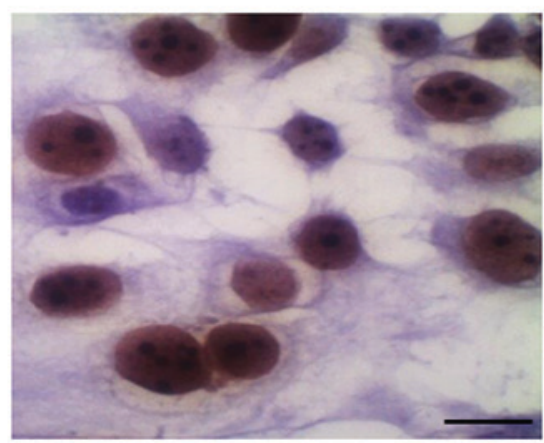

G

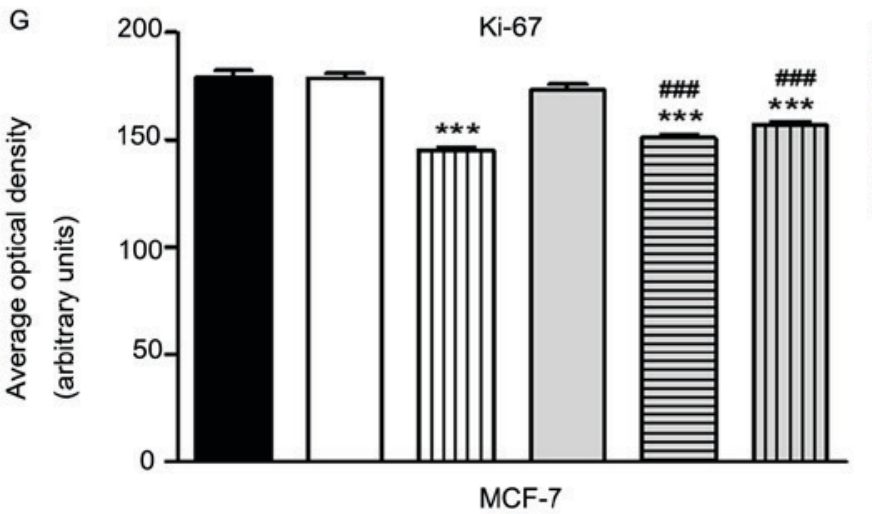

B

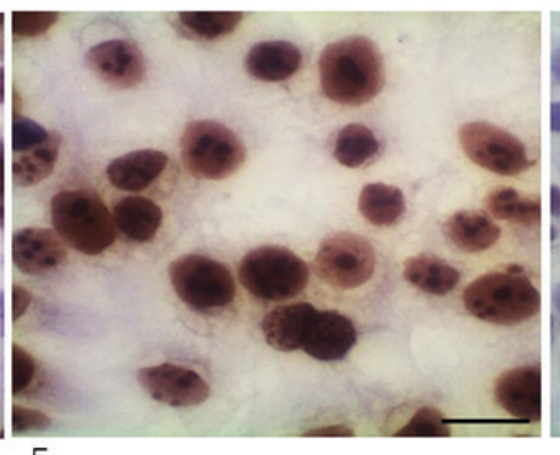

E

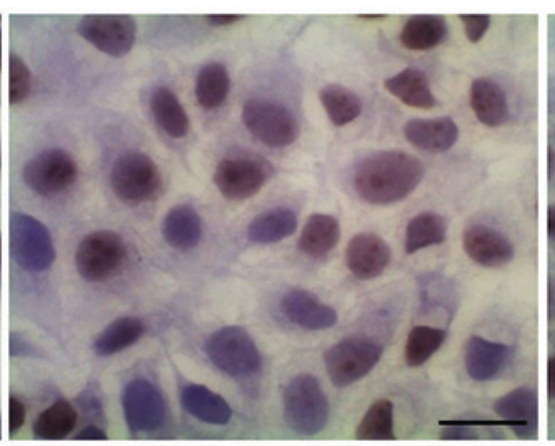

C

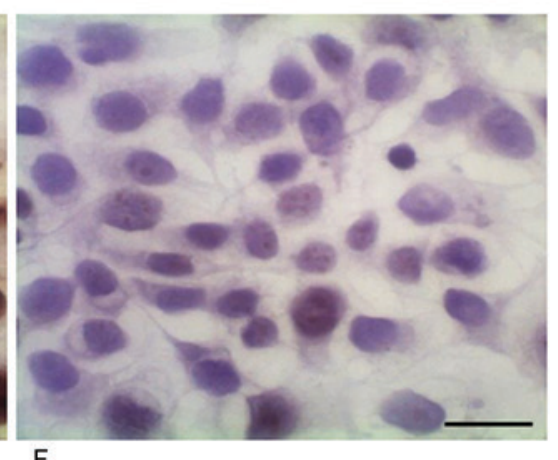

$\mathrm{F}$

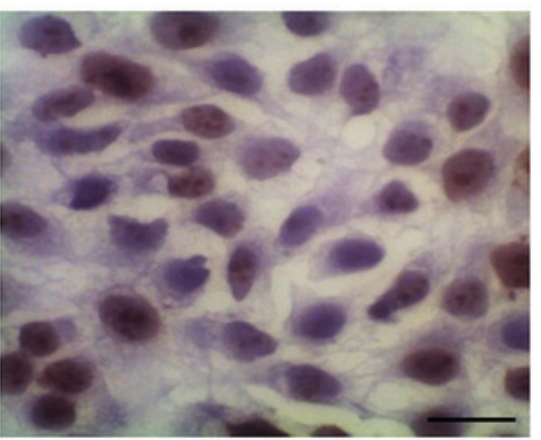

Figure 4. Analysis of expression of Ki-67 in MCF-7 cells. (A) Control cells (pH 7.2). (B) Cells after treatment with vehicle. (C) Post-treatment with melatonin $(1 \mathrm{mM})$ for $24 \mathrm{~h}$ decreases expression of Ki-67. (D) Cells under acidosis ( $\mathrm{pH}$ 6.7) have increased Ki-67 expression. (E) Cells exposed to the pH 6.7 treated concomitantly with melatonin $(1 \mathrm{mM})$ for $24 \mathrm{~h}$. (F) Cells exposed to the $\mathrm{pH} 6.7$ treated with melatonin $(1 \mathrm{mM})$ for $12 \mathrm{~h}$. Scale bar=10 $\mu$ m. Magnification, $\mathrm{x} 40$. (G) Densitometric analysis of Ki-67 expression. Results were obtained as mean \pm SEM densitometric index of three independent experiments done in triplicate.

*** $\mathrm{P}<0.001$ vs. control; ${ }^{\# \#} \mathrm{P}<0.001$ vs. acidosis. SEM, standard error of the mean.

immunocytochemistry in MCF-7 and MDA-MB-231 cell lines under normal conditions and acidosis. Densitometric analysis showed an increase in expression of GLUT-1 under acidosis conditions and a decrease in expression after treatment with melatonin in both cell lines. The upregulation of GLUT-1 was observed in a variety of tumors and it is clearly associated with tumor progression (40). Although the metabolic consequences of increased glucose transport are not understood, GLUT-1 expression seems to have significant clinical function in several tumors (41). The fast tumor growth induces metabolic changes in tumor cells to increase the consumption of glucose and supply the large energetic cost required by the intense activity of cell proliferation and accelerated metabolism. To maintain homeostasis of the tumor environment, tumor cells undergo anaerobic glycolysis, which leads to a high consumption of glucose; this activity is dependent on the GLUT-1 transporter (42). The treatment with melatonin $(1 \mathrm{mM})$ reduces the GLUT-1 expression in normal conditions and under acidosis. The effects of melatonin in GLUTs expression are not well established. Hevia et al (43) showed that melatonin competes with glucose to bind the GLUT-1 receptor decreasing the glucose uptake and GLUT-1 expression in prostate cancer cells. The authors suggested that melatonin can be transported by GLUT-1, increasing its intracellular levels (43).

A similar effect was observed for Ki-67. Analysis of Ki-67 protein expression by immunocytochemistry showed that melatonin decreases Ki-67 protein levels under acidosis conditions and it also decrease after melatonin treatment in both cell lines. Hill and Black (1988) showed that melatonin inhibits MCF-7 cell proliferation (44). It is true that melatonin has many anti-tumor properties, including anti-proliferative and pro-apoptotic actions, broadly investigated in many tumor 
A

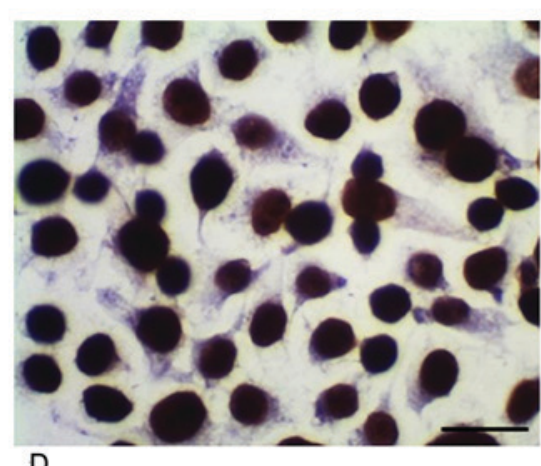

D

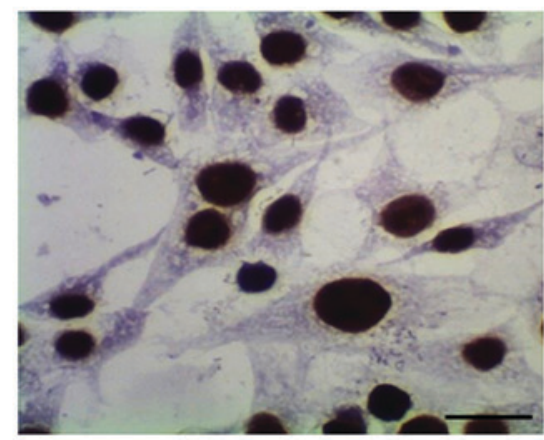

G

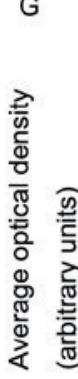

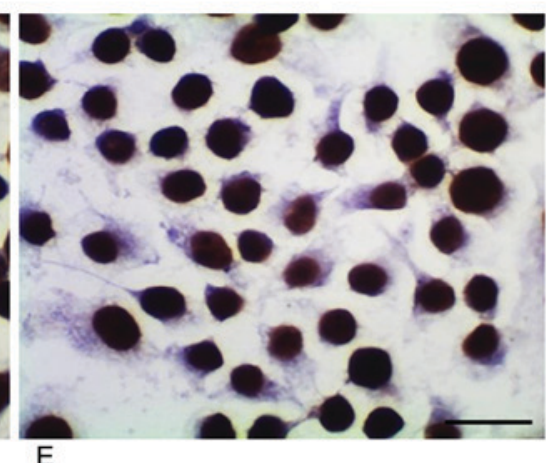

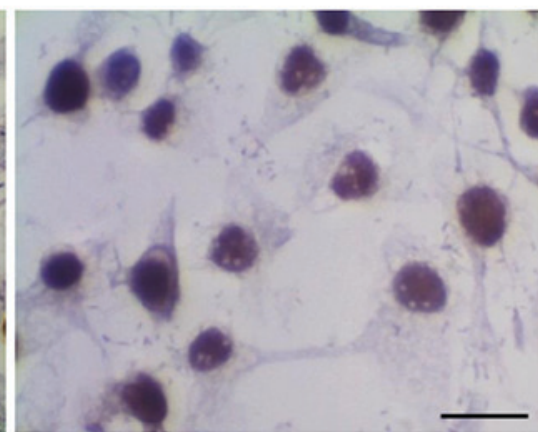

$\mathrm{F}$
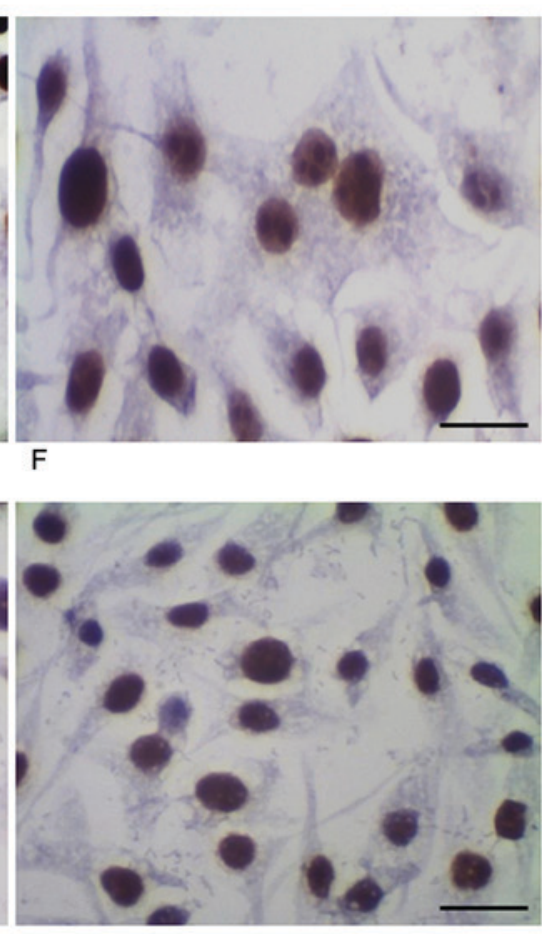

Control

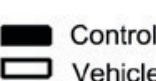

melatonin

$\square$ Acidosis

Acidosis+Melatonin $12 \mathrm{~h}$

m Incidosis+Mealatonin $24 \mathrm{~h}$

Figure 5. Analysis expression of Ki-67 in MDA-MB-231 cells. (A) Control cells (pH 7.2). (B) Cells after treatment with vehicle. (C) Post-treatment with melatonin (1 mM) for $24 \mathrm{~h}$ decreases expression of Ki-67. (D) Cells under acidosis ( $\mathrm{pH}$ 6.7) have increased Ki-67 expression. (E) Cells exposed to the pH 6.7 treated concomitantly with melatonin $(1 \mathrm{mM})$ for $24 \mathrm{~h}$. (F) Cells exposed to the $\mathrm{pH} 6.7$ treated with melatonin $(1 \mathrm{mM})$ for $12 \mathrm{~h}$. Scale bar=10 $\mu \mathrm{m}$. Magnification, $\mathrm{x} 40$. (G) Densitometric analysis of Ki-67 expression. Results were obtained as mean \pm SEM densitometric index of three independent experiments done in triplicate.

**** $\mathrm{P}<0.001$ vs. control; ${ }^{\# \# \#} \mathrm{P}<0.001$ vs. acidosis. SEM, standard error of the mean.

types especially in breast cancer $(45,46)$. However it is poorly understood how these effects correlate with breast cancer proliferation under acidosis conditions particularly with the Ki-67 protein expression, a known cell proliferation biomarker used for breast cancer prognosis (47). Based on this, the Ki-67 expression was evaluated in cell lines under acidosis treated with melatonin and the results showed a decrease in $\mathrm{Ki}-67$ expression after 12 and $24 \mathrm{~h}$ of treatment. These data corroborate with other studies that showed a significant decrease in Ki-67 expression in MCF-7 cells after treatment with melatonin $(46,48)$. Lower expression of Ki-67 was also showed in a previous study using nude mice with breast cancer treated with $40 \mathrm{mg} / \mathrm{kg}$ of melatonin for 21 days (35).

Danielczyk and Dziegiel (49) examined the relationship between expression of melatonin MT1 receptors and the level of Ki-67 in dermal melanoma (primary tumours and metastatic lymph nodes). In both, primary and metastasis, a very weak correlation was disclosed between MT1 and Ki-67 expression. Taken together these observations published so far suggest a variable relation between the expression of Ki-67 and melatonin. This relationship depends on the type of cell and tumor involved, as suggested by the authors (49).

The melatonin effect on GLUT- 1 and Ki-67 protein expression have already been described only in melanoma (50) and prostate cancer (43). Studies that analyze the induction of melatonin apoptosis are based on its kinetic suppression effect on cell growth and on its metabolic activity in breast cancer. Thus, studies involving molecular mechanisms of this action are still scarce. So, the molecular pathways of melatonin on the expression of GLUT-1 and Ki-67 still unclear. Moreover, further experiments should be done in order to investigate the possible mechanisms that melatonin is involved. 
A

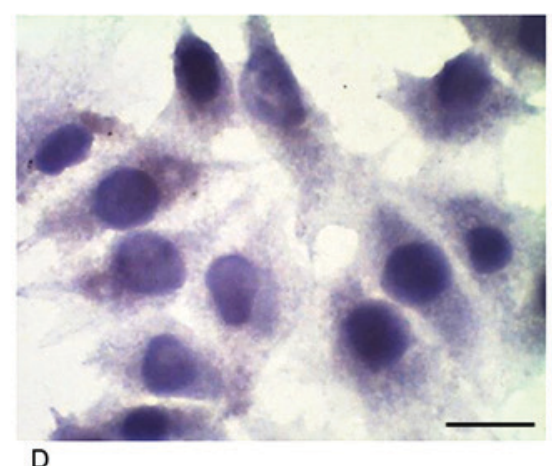

D

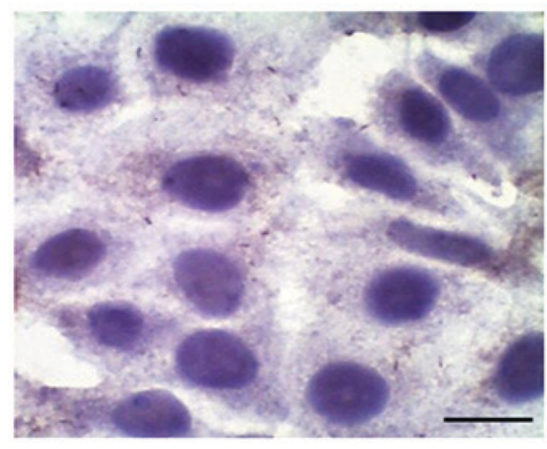

G

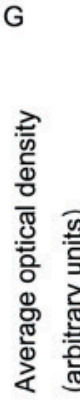

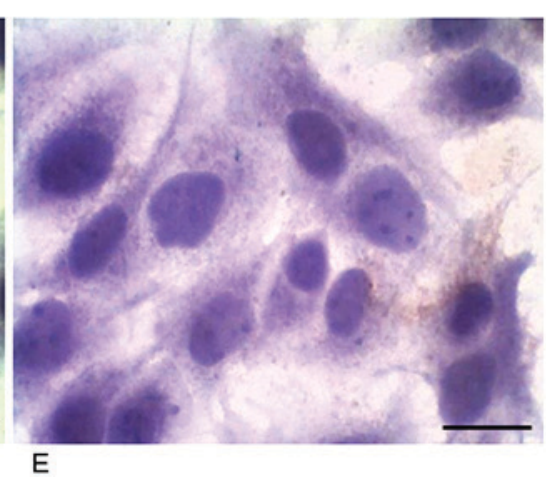

C

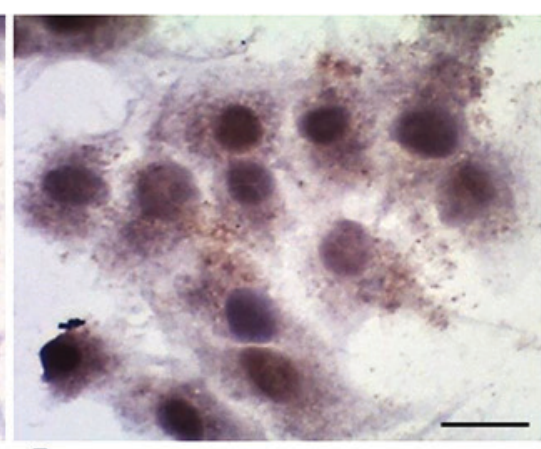

$\mathrm{F}$
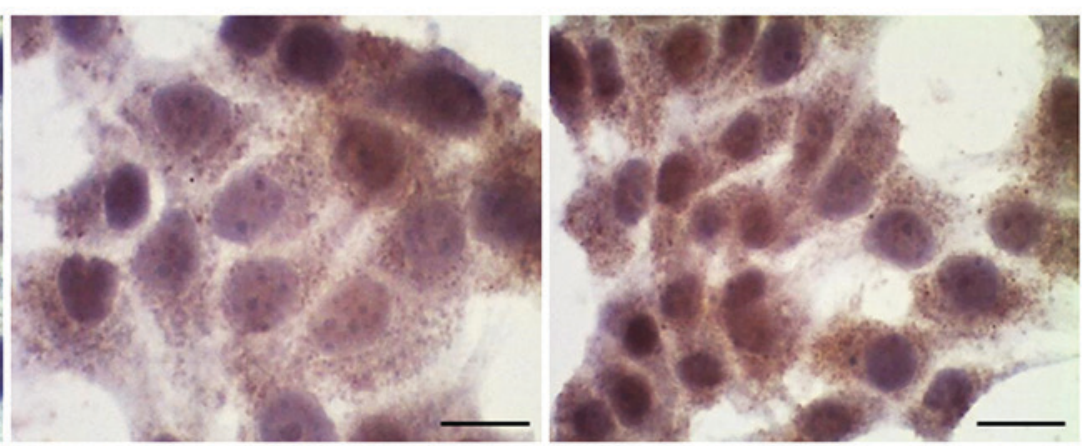

Control

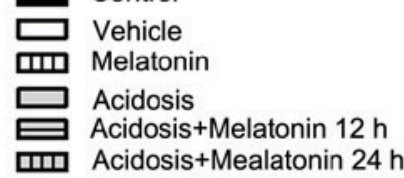

Caspase-3

Acidosis+Mealatonin $24 \mathrm{~h}$

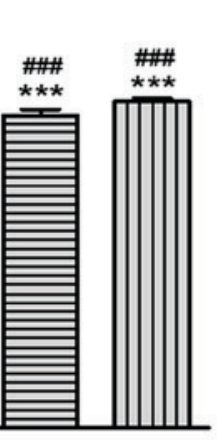

Figure 6. Analysis of Caspase-3 (cleaved) expression in MCF-7 cells. (A) Control group (pH 7.2). (B) Cells treated with vehicle only. (C) Post-treatment with melatonin (1 mM) for $24 \mathrm{~h}$ increased the expression of Caspase-3. (D) Cells under acidosis ( $\mathrm{pH}$ 6.7) have decreased expression of Caspase-3. (E) Cells exposed to the $\mathrm{pH} 6.7$ and treated concomitantly with melatonin $(1 \mathrm{mM})$ for $24 \mathrm{~h}$. (F) Cells exposed to the $\mathrm{pH} 6.7$ treated with melatonin $(1 \mathrm{mM})$ for $12 \mathrm{~h}$. Scale bar $=10 \mu \mathrm{m}$. Magnification, $\mathrm{x} 40$. (G) Densitometric analysis of the expression of Caspase-3. Results were obtained as mean \pm SEM densitometric index of three independent experiments done in triplicate. ${ }^{* * * *} \mathrm{P}<0.001$ vs. control; ${ }^{\# \#} \mathrm{P}<0.001$ vs. acidosis. SEM, standard error of the mean.

Differently of the regulation of melatonin in the expression of GLUT-1 and Ki-67, the expression of Capase-3 after treatment increases its protein levels under normal conditions and acidosis in both tumor cell lines. The modulation of Caspases by melatonin was previous showed only in leukemia cells, but not in breast cancer cell lines (51). Regarding the pro-apoptotic effect, studies have shown that melatonin is able to induce apoptosis activating the Caspase-3 pathway. This enzyme acts as an executor of apoptosis so, once it is activated, the programmed cell death begins irreversibly (52). In normal cells, there are two apoptosis-related pathways: The intrinsic and extrinsic pathway, the intrinsic pathway implicates the participation of the mitochondria. Studies suggest that melatonin causes translocation of the Cytochrome $\mathrm{c}$ from inside the mitochondria to the extracellular matrix through unspecific pores triggering the Caspase- 9 and subsequent the Caspase-3 activation (52). Therefore this mechanism may explain our data where melatonin administration in both cell lines has increased the Caspase-3 levels with subsequent cell death. An additional method to assess apoptosis is the TUNEL assay (Terminal deoxyribonucleotidyl transferase (TDT)-mediated dUTP-digoxigenin nick end labeling), which detects DNA fragments in situ. However, DNA fragmentation is common to different types of cell death and its in situ detection should not be considered as a specific marker of apoptosis (53).

Models demonstrate that different evolutionary trajectories may occur in adaptation to hypoxia and acidosis, but will generally converge to a final phenotype with constitutive upregulation of glycolysis and resistance to acid-induced toxicity (26). Taken together, our results show that melatonin treatment decreases the cell proliferation and GLUT-1 protein 
A
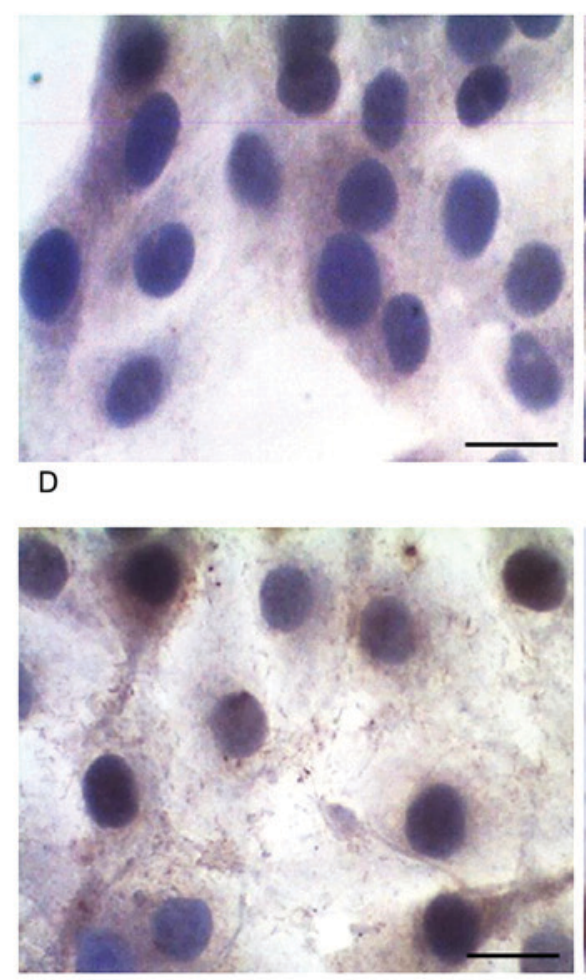

G

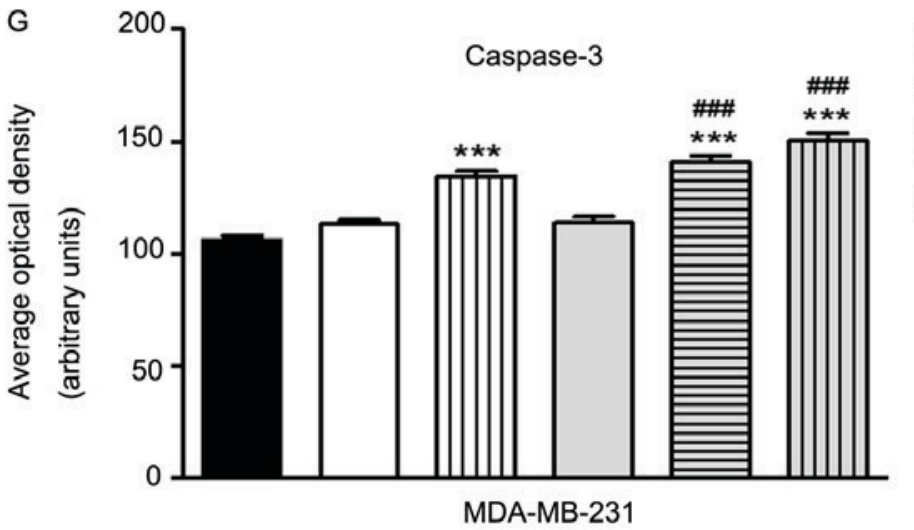

B

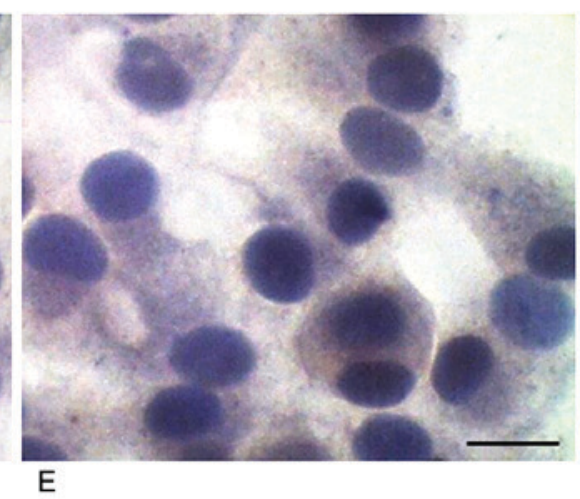

C

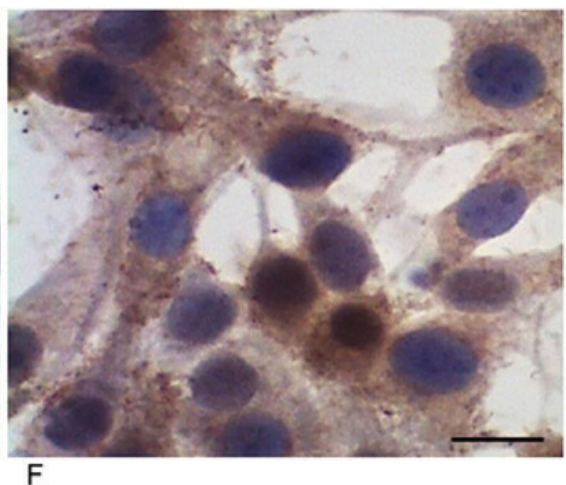

$\mathrm{F}$
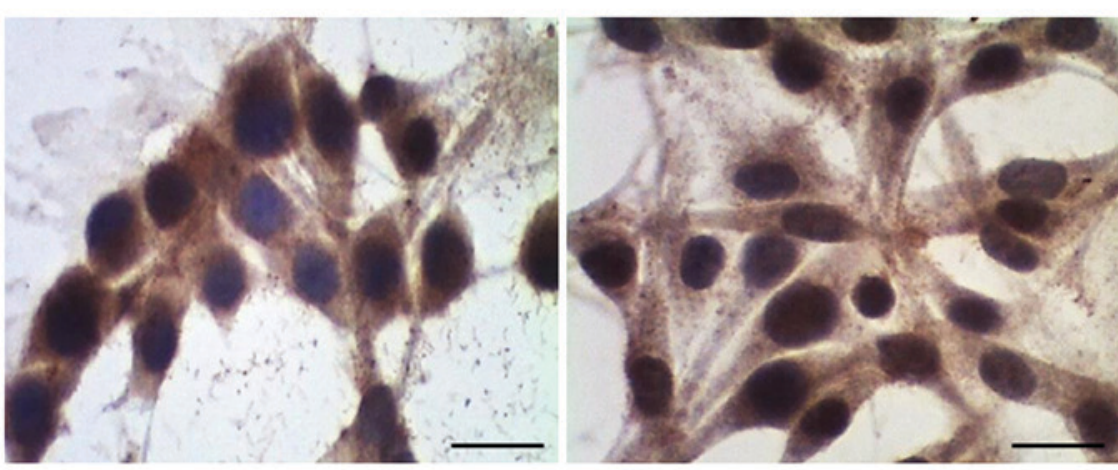

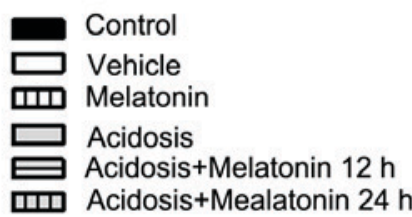

MDA-MB-231

Figure 7. Analysis of Caspase-3 (cleaved) expression in MDA-MB-231 cells. (A) Control group (pH 7.2). (B) Cells treated with vehicle only. (C) Post-treatment with melatonin $(1 \mathrm{mM})$ for $24 \mathrm{~h}$ decreases the expression of Caspase-3. (D) Cells under acidosis (pH 6.7) have increased expression of Caspase-3. (E) Cells exposed to the $\mathrm{pH} 6.7$ and treated concomitantly with melatonin $(1 \mathrm{mM})$ for $24 \mathrm{~h}$. (F) Cells exposed to the $\mathrm{pH} 6.7$ treated with melatonin $(1 \mathrm{mM})$ for $12 \mathrm{~h}$. Scale bar $=10 \mu \mathrm{m}$. Magnification, $\mathrm{x} 40$. (G) Densitometric analysis of the expression of Caspase-3. Results were obtained as mean \pm SEM densitometric index of three independent experiments done in triplicate. ${ }^{* * * *} \mathrm{P}<0.001$ vs. control; ${ }^{\# \# t} \mathrm{P}<0.001$ vs. acidosis. SEM, standard error of the mean.

expression and increase the apoptosis under acute acidosis in breast cancer cell lines. The analysis of the expression of the caspase-3, Ki-67 and GLUT-1 markers have been poorly studied using in vitro assays with breast cancer cells, especially in MDA-MB-231 and MCF-7, highlighting that our results present different data from the current literature. In conclusion, we have proposed in this report that melatonin has the ability to prevent the aggressive phenotype cell shifting of the mammary tumor cell lines under acidosis condition. It is noteworthy that several evidences showed that melatonin is a potential adjuvant therapeutic target for breast cancer but is required further investigations for a deeper understanding of the regulating mechanism of breast tumor under acidosis environment.

\section{Acknowledgements}

The authors would like to thank Conselho Nacional de Desenvolvimento Científico e Tecnológico - CNPq (grant no. 138094/2014-4) and Fundação de Amparo à Pesquisa do Estado de São Paulo - FAPESP (grant no. 13194-0/2014) for the scholarship. In addition, the authors would like to thank the Laboratorio de Investigaçao Molecular do Cancer (LIMC) from Faculdade de Medicina de Sao Jose do Rio Preto (FAMERP) for providing the materials and facilities to carry out this study.

\section{Competing interests}

The authors declare that they have no competing interests. 


\section{References}

1. Ferlay J, Parkin DM and Steliarova-Foucher E: Estimates of cancer incidence and mortality in Europe in 2008. Eur J Cancer 46: 765-781, 2010

2. Stevens RG, Brainard GC, Blask DE, Lockley SW and Motta ME: Breast cancer and circadian disruption from electric lighting in the modern world. CA Cancer J Clin 64: 207-218, 2014.

3. Prat A and Perou CM: Deconstructing the molecular portraits of breast cancer. Mol Oncol 5: 5-23, 2011.

4. Engelhardt EG, Garvelink MM, de Haes JH, van der Hoeven JJ, Smets EM, Pieterse AH and Stiggelbout AM: Predicting and communicating the risk of recurrence and death in women with early-stage breast cancer: A systematic review of risk prediction models. J Clin Oncol 32: 238-250, 2014

5. Gonzalez-Angulo AM, Morales-Vasquez F and Hortobagyi GN: Overview of resistance to systemic therapy in patients with breast cancer. Adv Exp Med Biol 608: 1-22, 2007.

6. Hicks DG and Kulkarni S: Trastuzumab as adjuvant therapy for early breast cancer: The importance of accurate human epidermal growth factor receptor 2 testing. Arch Pathol Lab Med 132: 1008-1015, 2008

7. Gralow J, Ozols RF, Bajorin DF, Cheson BD, Sandler HM, Winer EP, Bonner J, Demetri GD, Curran W Jr, Ganz PA, et al: Clinical cancer advances 2007: Major research advances in cancer treatment, prevention, and screening-a report from the American Society of Clinical Oncology. J Clin Oncol 26: 313-325, 2008

8. Duffy MJ, O'Donovan N and Crown J: Use of molecular markers for predicting therapy response in cancer patients. Cancer Treat Rev 37: 151-159, 2011

9. Hsiao YH, Chou MC, Fowler C, Mason JT and Man YG: Breast cancer heterogeneity: Mechanisms, proofs, and implications J Cancer 1: 6-13, 2010.

10. Lewis-Wambi JS and Jordan VC: Treatment of postmenopausal breast cancer with Selective Estrogen Receptor Modulators (SERMs). Breast Dis 24: 93-105, 2005-2006.

11. Dauchy RT, Xiang S, Mao L, Brimer S, Wren MA, Yuan L, Anbalagan M, Hauch A, Frasch T, Rowan BG, et al: Circadian and melatonin disruption by exposure to light at night drives intrinsic resistance to tamoxifen therapy in breast cancer. Cancer Res 74: 4099-4110, 2014

12. Fernandes RC, Bevilacqua JL, Soares IC, Siqueira SA, Pires L, Hegg R and Carvalho FM: Coordinated expression of ER, PR and HER 2 define different prognostic subtypes among poorly differentiated breast carcinomas. Histopathology 55: 346-352, 2009.

13. Cao MD, Lamichhane S, Lundgren S, Bofin A, Fjøsne $\mathrm{H}$, Giskeødegård GF and Bathen TF: Metabolic characterization of triple negative breast cancer. BMC Cancer 14: 941, 2014.

14. Kaplan HG and Malmgren JA: Impact of triple negative phenotype on breast cancer prognosis. Breast J 14: 456-463, 2008.

15. Qiu F, Chen YR, Liu X, Chu CY, Shen LJ, Xu J, Gaur S Forman HJ, Zhang H, Zheng S, et al: Arginine starvation impairs mitochondrial respiratory function in ASS1-deficient breast cancer cells. Sci Signal 7: ra31, 2014.

16. Justus CR, Sanderlin EJ and Yang LV: Molecular connections between cancer cell metabolism and the tumor microenvironment. Int J Mol Sci 16: 11055-11086, 2015.

17. Rundqvist $\mathrm{H}$ and Johnson RS: Tumour oxygenation: Implications for breast cancer prognosis. J Intern Med 274: 105-112, 2013.

18. Mekhail K, Gunaratnam L, Bonicalzi ME and Lee S: HIF activation by $\mathrm{pH}$-dependent nucleolar sequestration of VHL. Nat Cell Biol 6: 642-647, 2004

19. Swietach P, Vaughan-Jones RD and Harris AL: Regulation of tumor $\mathrm{pH}$ and the role of carbonic anhydrase 9. Cancer Metastasis Rev 26: 299-310, 2007.

20. Maschio LB, Madallozo BB, Capellasso BA, Jardim BV, Moschetta MG, Jampietro J, Soares FA and Zuccari DA: Immunohistochemical investigation of the angiogenic proteins VEGF, HIF-1 $\alpha$ and CD34 in invasive ductal carcinoma of the breast. Acta Histochem 116: 148-157, 2014.

21. Harris AL: Hypoxia-A key regulatory factor in tumour growth Nat Rev Cancer 2: 38-47, 2002.

22. Warburg O: On the origin of cancer cells. Science 123: 309-314, 1956.

23. Yu L, Chen X, Wang L and Chen S: The sweet trap in tumors: Aerobic glycolysis and potential targets for therapy. Oncotarget 7 : 38908-38926, 2016.
24. Wu H, Ding Z, Hu D, Sun F, Dai C, Xie J and Hu X: Central role of lactic acidosis in cancer cell resistance to glucose deprivation-induced cell death. J Pathol 227: 189-199, 2012.

25. Xu K, Mao X, Mehta M, Cui J, Zhang C, Mao F and Xu Y: Elucidation of how cancer cells avoid acidosis through comparative transcriptomic data analysis. PLoS One 8: e71177, 2013.

26. Gatenby RA, Gawlinski ET, Gmitro AF, Kaylor B and Gillies RJ: Acid-mediated tumor invasion: A multidisciplinary study. Cancer Res 66: 5216-5223, 2006.

27. De Milito A, Canese R, Marino ML, Borghi M, Iero M, Villa A, Venturi G, Lozupone F, Iessi E, Logozzi M, et al: pH-dependent antitumor activity of proton pump inhibitors against human melanoma is mediated by inhibition of tumor acidity. Int J Cancer 127: 207-219, 2010.

28. Stüwe L, Müller M, Fabian A, Waning J, Mally S, Noël J, Schwab A and Stock C: $\mathrm{pH}$ dependence of melanoma cell migration: Protons extruded by NHE1 dominate protons of the bulk solution. J Physiol 585: 351-360, 2007.

29. Hill SM, Belancio VP, Dauchy RT, Xiang S, Brimer S, Mao L, Hauch A, Lundberg PW, Summers W, Yuan L, et al: Melatonin: An inhibitor of breast cancer. Endocr Relat Cancer 22: R183-R204, 2015.

30. Coto-Montes A, Boga JA, Tan DX and Reiter RJ: Melatonin as a potential agent in the treatment of sarcopenia. Int J Mol Sci 17: pii: E1771, 2016.

31. Mediavilla MD, Sanchez-Barcelo EJ, Tan DX, Manchester L and Reiter RJ: Basic mechanisms involved in the anti-cancer effects of melatonin. Curr Med Chem 17: 4462-4481, 2010.

32. Nooshinfar E, Safaroghli-Azar A, Bashash D and Akbari ME: Melatonin, an inhibitory agent in breast cancer. Breast Cancer 24: 42-51, 2017

33. Alvarez-García V, González A, Alonso-González C, Martínez-Campa C and Cos S: Regulation of vascular endothelial growth factor by melatonin in human breast cancer cells. J Pineal Res 54: 373-380, 2013.

34. Mao L, Summers W, Xiang S, Yuan L, Dauchy RT, Reynolds A, Wren-Dail MA, Pointer D, Frasch T, Blask DE and Hill SM: Melatonin represses metastasis in Her2-postive human breast cancer cells by suppressing RSK2 expression. Mol Cancer Res 14: 1159-1169, 2016.

35. Jardim-Perassi BV, Arbab AS, Ferreira LC, Borin TF, Varma NR, Iskander AS, Shankar A, Ali MM and de Campos Zuccari DA: Effect of melatonin on tumor growth and angiogenesis in xenograft model of breast cancer. PLoS One 9: e85311, 2014.

36. Gatenby RA, Smallbone K, Maini PK, Rose F, Averill J, Nagle RB, Worrall L and Gillies RJ: Cellular adaptations to hypoxia and acidosis during somatic evolution of breast cancer. Br J Cancer 97: 646-653, 2007.

37. Borin TF, Arbab AS, Gelaleti GB, Ferreira LC, Moschetta MG, Jardim-Perassi BV, Iskander AS, Varma NR, Shankar A, Coimbra VB, et al: Melatonin decreases breast cancer metastasis by modulating Rho-associated kinase protein-1 expression. J Pineal Res 60: 3-15, 2016.

38. Gonçalves Ndo N, Colombo J, Lopes JR, Gelaleti GB, Moschetta MG, Sonehara NM, Hellmén E, Zanon Cde F, Oliani SM and Zuccari DA: Effect of melatonin in epithelial mesenchymal transition markers and invasive properties of breast cancer stem cells of canine and human cell lines. PLoS One 11: e0150407, 2016.

39. Wojtkowiak JW, Rothberg JM, Kumar V, Schramm KJ, Haller E, Proemsey JB, Lloyd MC, Sloane BF and Gillies RJ: Chronic autophagy is a cellular adaptation to tumor acidic $\mathrm{pH}$ microenvironments. Cancer Res 72: 3938-3947, 2012.

40. Macheda ML, Rogers S and Best JD: Molecular and cellular regulation of glucose transporter (GLUT) proteins in cancer. J Cell Physiol 202: 654-662, 2005.

41. Oliver RJ, Woodwards RT, Sloan P, Thakker NS, Stratford IJ and Airley RE: Prognostic value of facilitative glucose transporter Glut-1 in oral squamous cell carcinomas treated by surgical resection; Results of EORTC Translational Research Fund studies. Eur J Cancer 40: 503-507, 2004.

42. Suganuma N, Segade F, Matsuzu K and Bowden DW: Differential expression of facilitative glucose transporters in normal and tumour kidney tissues. BJU Int 99: 1143-1149, 2007.

43. Hevia D, González-Menéndez P, Quiros-González I, Miar A, Rodríguez-García A, Tan DX, Reiter RJ, Mayo JC and Sainz RM: Melatonin uptake through glucose transporters: A new target for melatonin inhibition of cancer. J Pineal Res 58: 234-250, 2015. 
44. Hill SM and Blask DE: Effects of the pineal hormone melatonin on the proliferation and morphological characteristics of human breast cancer cells (MCF-7) in culture. Cancer Res 48: 6121-6126, 1988.

45. Cos S and Sánchez-Barceló EJ: Melatonin and mammary pathological growth. Front Neuroendocrinol 21: 133-170, 2000.

46. Chottanapund S, Van Duursen MB, Navasumrit P, Hunsonti P, Timtavorn S, Ruchirawat M and Van den Berg M: Anti-aromatase effect of resveratrol and melatonin on hormonal positive breast cancer cells co-cultured with breast adipose fibroblasts. Toxicol In Vitro 28: 1215-1221, 2014.

47. Liu YX, Wang KR, Xing H,Zhai XJ, Wang LP and Wang W: Attempt towards a novel classification of triple-negative breast cancer using immunohistochemical markers. Oncol Lett 12: 1240-1256, 2016.

48. Czeczuga-Semeniuk, Wołczyński S, Anchim T, Dziecioł J, Dabrowska M and Pietruczuk M: Effect of melatonin and all-trans retinoic acid on the proliferation and induction of the apoptotic pathway in the culture of human breast cancer cell line MCF-7. Pol J Pathol 53: 59-65, 2002.

49. Danielczyk K and Dziegiel P: The expression of MT1 melatonin receptor and $\mathrm{Ki}-67$ antigen in melanoma malignum. Anticancer Res 29: 3887-3895, 2009.
50. Danielczyk K and Dziegiel P: MT1 melatonin receptors and their role in the oncostatic action of melatonin. Postepy Hig Med Dosw (Online) 63: 425-434, 2009 (In Polish).

51. Perdomo J, Cabrera J, Estévez F, Loro J, Reiter RJ and Quintana J: Melatonin induces apoptosis through a caspase-dependent but reactive oxygen species-independent mechanism in human leukemia Molt-3 cells. J Pineal Res 55: 195-206, 2013.

52. Chen X, Duan N, Zhang C and Zhang W: Survivin and tumorigenesis: Molecular mechanisms and therapeutic strategies. J Cancer 7: 314-323, 2016.

53. Grasl-Kraupp B, Ruttkay-Nedecky B, Koudelka H, Bukowska K, Bursch W and Schulte-Hermann R: In situ detection of fragmented DNA (TUNEL assay) fails to discriminate among apoptosis, necrosis, and autolytic cell death: A cautionary note. Hepatology 21: 1465-1468, 1995.

(i) This work is licensed under a Creative Commons Attribution 4.0 International (CC BY 4.0) License. 